\title{
Difference in optimum temperature for growth and reproduction in benthic foraminifer Rosalina globularis: Implications for paleoclimatic studies Rajeev Saraswat ${ }^{1}$, R. Nigam ${ }^{1}$, Sangita Pachkhande ${ }^{2}$
}

1 Micropaleontology Laboratory, Geological Oceanography Division, National Institute of Oceanography, Dona Paula, Goa

2 Department of Geology, University of Pune, Pune

* For Correspondence: rsaraswat@nio.org

\begin{abstract}
The seawater temperature is an important physical parameter that affects marine benthic community. The effect of seawater temperature however is not consistent throughout various groups of marine benthos. Here, juvenile specimens of marginal marine species Rosalina globularis were subjected to different temperatures $\left(20^{\circ} \mathrm{C}, 25^{\circ} \mathrm{C}, 27^{\circ} \mathrm{C}, 30^{\circ} \mathrm{C}\right.$ and $\left.35^{\circ} \mathrm{C}\right)$, to understand the effect of temperature on growth and reproduction in benthic foraminifera. The growth of the specimens was recorded till the specimens matured and reproduced. It was observed that out of five different temperatures, optimum growth took place at $30^{\circ} \mathrm{C}$. The growth in rest of the specimens subjected to either higher or lower temperatures was comparatively less. However, the highest percentage of reproduction was reported in the specimens subjected to $27^{\circ} \mathrm{C}$ temperature. None of the specimens kept at $20^{\circ} \mathrm{C}$ reproduced whereas only one specimen reproduced at $35^{\circ} \mathrm{C}$ temperature. Based on this experiment, it is concluded that Rosalina globularis can tolerate temperature variations from $20^{\circ} \mathrm{C}$ to $35^{\circ} \mathrm{C}$ and further that the optimum temperatures for growth and reproduction are different. The study shows that the ambient seawater temperature affects the growth, survival and reproduction in benthic foraminifera. The study further indicates that variation in morphology and abundance of benthic foraminifera, might reflect different climatic conditions.
\end{abstract}

Key words: Temperature, benthic foraminifera, growth, reproduction, Rosalina globularis 


\section{Introduction}

Benthic foraminifera (unicellular, largely marine microorganisms with exoskeleton made of calcite or agglutinated material) live in all diverse types of marine habitats and constitute a large part of benthic community in shallow marine waters. A majority of the paleoclimatic studies from the deeper oceanic regions are based on planktic foraminifera due to their high abundance in deeper ocean, whereas benthic foraminifera are preferred in such studies from shallow waters as planktic foraminifera are rare in near-shore environments. Benthic foraminifera from shallow water regions have been used to infer monsoon intensity, seawater temperature, productivity, oxygen availability, etc (Nigam et al., 1995; 2009; Hald et al., 1999; Leorri et al., 2006; Majewski \& Anderson, 2009; Hengstum et al., 2010). It is essential to understand the effect of change in physical and chemical parameters on the benthic foraminiferal population and morphology, to apply the benthic foraminiferal characteristics for paleoclimatic reconstruction. Numerous field studies show that seawater temperature, salinity, $\mathrm{pH}$, water depth, organic matter, oxygen, etc, affect benthic foraminiferal abundance, assemblage, morphology, isotopic composition, etc (Boltovskoy and Wright, 1976; Collins, 1989; Boltovskoy et al., 1991; Nigam and Khare, 1995; 1999; Gooday, 2003, Halfer and Ingle, 2003; Murray, 2006). The field studies have been supplemented by laboratory culture experiments on benthic foraminifera, which has improved our knowledge of effect of various physical and chemical parameters on benthic foraminifera (see Linshy et al., 2007 for review).

Both field and laboratory culture studies show that seawater temperature is among the few major seawater characteristics that affect benthic foraminiferal distribution and morphology in shallow water regions (Boltovskoy et al., 1991; Murray, 2006; Nigam et al., 2006; 2008). Benthic foraminifera are known to tolerate a wide temperature range $\left(-10{ }^{\circ} \mathrm{C}\right.$ to $\left.45^{\circ} \mathrm{C}\right)$ (Murray, 2006). The response of benthic foraminifera to temperature, however, seems to be species specific. While an increase in the size of the shells of several benthic foraminifera with decreasing temperature was noted by several workers (Bandy, 1963; Lewis and Jenkins, 1969), a few other studies indicated that the shell size decreases with drop in temperature (Phleger and Hamilton, 1946; Theyer, 1971). Besides size, the shape of the shell has also been reported to vary with seawater temperature (Schnitker, 1974; Walton and Sloan, 1990).

In such studies from the field (which are based on surface sediment samples collected from several locations), it is difficult to assign the change in benthic foraminiferal population to a particular parameter such as temperature. The laboratory culture studies can help overcome this problem since in laboratory culture it is possible to change only the seawater temperature while 
keeping all other parameters (salinity, food, $\mathrm{pH}$, etc) constant. Therefore, we decided to understand the effect of various physico-chemical parameters on shallow water benthic foraminifera by culturing live specimens under controlled conditions in laboratory. Here, we report the effect of seawater temperature on growth and reproduction in one shallow water benthic foraminifer Rosalina globularis. This species was chosen as it is common in shallow marine waters and is cosmopolitan. The objective was to assess the effect of seawater temperature on the growth and reproduction in $R$. globularis as previous studies suggested that the mode of reproduction (sexual/asexual) in this species was temperature dependent (Myers, 1943), though later studies did not confirm it (Sliter, 1965). Additionally, earlier studies also reported peculiar temporary pelagic stage (known as 'tretomphalus' stage) during reproduction in Rosalina globularis (Myers, 1943), whose presence was also debated (Sliter, 1965).

\section{Methodology}

\section{A. Collection and separation of live specimens}

To get live specimens of Rosalina globularis, the materials, including surface sediment samples and sea-grass were collected from waters off Goa. The material collected from the sampling location was sieved through $63 \mu \mathrm{m}$ size sieve and $>63 \mu \mathrm{m}$ material was brought to the laboratory. Sea water was also collected at the time of sampling. In the laboratory, the $>63 \mu \mathrm{m}$ material was scanned under the stereo-zoom microscope (Olympus SZX-16) to pick live specimens. The live specimens were picked using a micropipette or a very fine brush. These live specimens were then transferred to multi-well (6-wells) culture dishes (Nunclan). The live status of the specimens was further confirmed by observing activities like movement, collection of food, pseudopodial extension, etc, under the inverted microscope (Nikon ECLIPSE TE2000-U). Once confirmed to be live, the specimens were divided into several batches and kept at different ecological conditions (salinity varying from 20\%o to $40 \%$ and temperature varying from $15^{\circ} \mathrm{C}$ to $30^{\circ} \mathrm{C}$ ) to facilitate reproduction. The offspring of the reproduced specimens, that is the juveniles with two-three chambers, were subjected to different temperatures. The advantage of conducting experiments on juveniles is that there is ample time for specimens to respond to physico-chemical conditions, before they mature and reproduce.

\section{B. The Experiment}

The juvenile specimens of Rosalina globularis were subjected to different temperatures $\left(20{ }^{\circ} \mathrm{C}, 25\right.$ ${ }^{\circ} \mathrm{C}, 27^{\circ} \mathrm{C}, 30^{\circ} \mathrm{C}$ and $35^{\circ} \mathrm{C}$ ), whereas the salinity was kept constant (35\%o). This range of seawater 
temperature was selected based on continuous monitoring of physico-chemical parameters in the field from where live specimens were collected (Rodrigues, 1984; Nigam et al., 2008). Initially, all the specimens were kept at $27^{\circ} \mathrm{C}$ temperature and $35 \%$ salinity as this was the temperature-salinity combination at which the specimens reproduced. Five specimens were kept in each well of the sixwelled culture tray. Each well has a diameter of $35 \mathrm{~mm}$ and height $20 \mathrm{~mm}$. The working volume of each well was $10 \mathrm{ml}$. Thus, 30 specimens were subjected to each temperature. The experiment was carried out in replicate. The temperature was changed (increased or decreased) gradually in order to prevent a sudden experimental shock, which the organisms could experience if they were transferred directly to the respective intended temperatures. On day 1 , all the trays were kept at $27{ }^{\circ} \mathrm{C}$ temperature. On day 2, temperature of the media in tray 1 and tray 2 was lowered to $25^{\circ} \mathrm{C}$, whereas the seawater temperature in tray 4 and tray 5 was increased to $30{ }^{\circ} \mathrm{C}$. One of the trays was maintained at the same temperature $\left(27^{\circ} \mathrm{C}\right)$. On day 4 , temperature of tray 1 was further lowered to $23^{\circ} \mathrm{C}$, whereas that of tray 5 was increased to $33^{\circ} \mathrm{C}$; trays 2,3 and 4 were maintained as on previous day. On day 6, tray 1 was shifted to $20^{\circ} \mathrm{C}$, whereas temperature of tray 5 was increased to $35^{\circ} \mathrm{C}$. The rest of the trays were maintained as on the previous day. Thus by day 6, all the trays had the desired temperatures and this set up was maintained till the end of the experiment (Fig. 1). The maximum diameter of all the specimens was measured every third day under inverted microscope (Nikon Eclipse TE 2000-U) connected to computer by using ACT 2U (Auto Camera Tame to you/Utility) software. To measure the maximum diameter, specimens were kept in spiral view. The media in the culture dishes (natural seawater) was changed every alternate day. To maintain the set temperature with minimal deviation $\left( \pm 0.5^{\circ} \mathrm{C}\right)$, culture trays were kept in cooling incubators (Remi CI-3S).

\section{The Food}

Live diatom Navicula (100 ml solution, 20 cells) was added as food, every time the medium was changed. This diatom species was chosen for food since foraminifers feed on diatoms and Navicula species has been reported from the area from where material for live specimens was collected. The Navicula stock was maintained by batch subculture method. The diatom was grown in $\mathrm{F}_{2}$ medium. The $F_{2}$ medium was prepared by following the method described by Guillard and Ryther (1962). The medium was stored in refrigerator and was used to subculture Navicula. Before sub-culturing, the $\mathrm{F}_{2}$ media was removed from the refrigerator and kept in laminar flow to bring it to the room temperature. Once the $\mathrm{F}_{2}$ medium was brought to the room temperature, about $50 \mathrm{ml}$ of it was poured into the properly labeled and autoclaved $100 \mathrm{ml}$ conical flasks. Subsequently, from the earlier diatom 
culture $\sim 200 \mu \mathrm{l}$ was taken with the help of micropipette and poured in the flasks. These flasks were then kept at $27^{\circ} \mathrm{C}$ and $30^{\circ} \mathrm{C}$ temperature.

\section{Results}

Growth was observed in all the specimens right from the beginning and continued for $\sim 43$ days (Fig. 2). Distinct differences, however, were noted in the growth of specimens kept at different temperatures. The specimens kept at $30^{\circ} \mathrm{C}$ temperature attained maximum growth $(193 \mu \mathrm{m})$ compared to the specimens subjected to both higher as well as lower temperatures. The average growth attained by specimens subjected to $30^{\circ} \mathrm{C}$ was $\sim 193 \mu \mathrm{m}$, whereas average growth attained by specimens subjected to $35^{\circ} \mathrm{C}$ temperature was $\sim 152 \mu \mathrm{m}$. Specimens subjected to $27^{\circ} \mathrm{C}$ temperature attained average growth of $\sim 125 \mu \mathrm{m}$. The growth decreased with further decrease in temperature. At $25^{\circ} \mathrm{C}$ temperature, the specimens grew to an average size of $\sim 99 \mu \mathrm{m}$ whereas minimum growth ( $\sim 88$ $\mu \mathrm{m}$ ) was noted at $20^{\circ} \mathrm{C}$ temperature. After $\sim 43$ days, it was observed that either the growth in all the specimens stopped or the specimens reproduced. The average maximum size attained by $R$. globularis (at $30^{\circ} \mathrm{C}$ ) was comparable with its average size in the field ( 216 $\left.\pm 74 \mu \mathrm{m}\right)$. The growth attained at other temperatures was much lower than its average size as reported in field sediments.

The specimens reproduced only asexually (Plate 1). The maximum percentage of reproduction was observed in specimens subjected to $27^{\circ} \mathrm{C}$ temperature (Fig. 3). Around $80 \%$ specimens subjected to $27^{\circ} \mathrm{C}$ temperature reproduced. At $30^{\circ} \mathrm{C}$ temperature, only $\sim 40 \%$ specimens reproduced, whereas, out of all the specimens subjected to $25^{\circ} \mathrm{C}$ temperature, $\sim 25 \%$ reproduced. Additionally, it was observed that the reproduction in specimens subjected to $25^{\circ} \mathrm{C}$ temperature was abnormal. The number of offspring was less (varying from 10 to 30 ) in specimens subjected to $25^{\circ} \mathrm{C}$ temperature as compared to the number of juveniles in the specimens subjected to other temperatures (varying from 30 to 120 ). At $35^{\circ} \mathrm{C}$, only $\sim 6 \%$ specimen reproduced. None of the specimens out of all those which were subjected to $20^{\circ} \mathrm{C}$ temperature, reproduced.

\section{Discussion}

In this experiment, it was observed that though the growth of Rosalina globularis does not vary linearly with seawater temperature, the growth, in general, was more at relatively warmer temperatures, whereas stunted specimens were noticed at lower temperatures. The seawater temperature is one of the abiotic factors that affect marine organisms as it controls several vital activities including survival, growth, reproduction etc. As early as 1856, Carpenter suggested that 
temperature could play an important role in the morphological variations of the foraminiferal tests. Phleger and Hamilton (1946) also made similar conclusions based on the study of shell size in two widely separated cores. The findings are further supported by earlier studies wherein larger specimens of Cyclammina cancellata were found at warmer shallow waters (Theyer, 1971). Our findings are also supported by Boltovskoy et al (1991) who summarized that decrease in temperature leads to smaller shells of the same species. This study also contradicts the findings of Nigam et al (2008) who noted that the specimens of Rosalina leei subjected to $25^{\circ} \mathrm{C}$ temperature showed more growth compared to the specimens subjected to $30^{\circ} \mathrm{C}$ and $35^{\circ} \mathrm{C}$ temperatures. This indicates that the species belonging to the same genus may have different temperature preferences. Though Bradshaw (1955; 1961) noted that at slightly lower temperatures the specimens could survive but eventually die, no such observation was made in this study. Probably the temperatures, to which specimens of Rosalina globularis were subjected to, in this study, were higher than its lower temperature tolerance limit.

The maximum growth at $30^{\circ} \mathrm{C}$, instead of still warmer temperatures, shows that this species has a narrow temperature limit for optimum growth. Similar observations were made in case of several benthic and planktic foraminiferal species (Boltovskoy and Wright, 1976; Bé and Tolderlund, 1971; Hemleben et al., 1989).

Another significant finding of this study is that the optimum temperature for growth and reproduction in Rosalina globularis is different. The maximum growth was attained by the specimens subjected to $30^{\circ} \mathrm{C}$ temperature, whereas maximum number of specimens subjected to $27^{\circ} \mathrm{C}$ temperatures reproduced. The optimum temperature for reproduction in most of the species does not match with the optimum temperature for shell growth (Boltovskoy and Wright, 1976). Though growth occurred in specimens subjected to $20^{\circ} \mathrm{C}$ temperature, none of the specimens reproduced. It might be because this temperature is out of narrow range of seawater temperature at which Rosalina globularis reproduces. Bradshaw (1955, 1957) also reported that several benthic foraminiferal species reproduce only at a very narrow temperature range. Additionally, the specimens subjected to $20^{\circ} \mathrm{C}$ temperature were alive till the end of the experiment. Previously, it was observed that outside the reproductive temperature limits, the foraminifera remain alive and yet not reproduce and also that though foraminifera reach maturity, they reproduce only if the environmental conditions are favorable (Bradshaw 1955, 1957). Nigam et al (2008) also noticed that, specimens of Rosalina leei did not reproduce at any of the temperatures to which they were subjected to in the laboratory $\left(25^{\circ} \mathrm{C}, 30^{\circ} \mathrm{C}\right.$ and $\left.35^{\circ} \mathrm{C}\right)$, but the specimens survived for longer time, as well as showed 
significant growth at all the three temperatures. They also suggested that none of the temperatures at which Rosalina leei was maintained in laboratory, was favorable for its reproduction.

It was also observed that, specimens of Rosalina globularis subjected to $25^{\circ} \mathrm{C}$ temperature reproduced but the reproduction was abnormal (only a few juveniles were released from the parent test). This shows that not only the instances of reproduction vary with temperature, but also the number of juveniles produced, depends on seawater temperature. The less number of juveniles in specimens subjected to lower temperature was probably due to the smaller size of the parent test. The average size of the specimens subjected to $25^{\circ} \mathrm{C}$ as well as $20^{\circ} \mathrm{C}$ temperature was smaller than the specimens maintained at moderate to higher temperatures $\left(27^{\circ} \mathrm{C}, 30^{\circ} \mathrm{C}\right.$ and $\left.35^{\circ} \mathrm{C}\right)$.

All the specimens reproduced asexually only during the course of the experiment. Although Myers (1940) reported an orderly sexual and asexual reproduction, subsequent studies showed that it successively reproduced asexually for upto a maximum of four generations (Sliter, 1965). Myers (1940) observed sexual reproduction in Rosalina globularis at temperatures $>18^{\circ} \mathrm{C}$, however, no sexual reproduction was observed in present study wherein it was subjected to temperatures much warmer than $18^{\circ} \mathrm{C}$. A temporary pelagic stage, termed as 'tretomphalus stage' was also reported during reproduction in $R$. globularis (Myers, 1940; Sliter, 1965). But no such stage was reported in this study. This stage is probably a part of sexual reproduction, which was not observed.

The maximum growth was observed in specimens subjected to $30^{\circ} \mathrm{C}$ temperature, whereas the maximum reproduction occurred at $27^{\circ} \mathrm{C}$ temperature. The growth indicates morphology of the species while the reproduction will affect the abundance. Therefore a difference in temperature of maximum growth and reproduction indicates that the morphology and abundance of benthic foraminifera reflect different climatic conditions. It is inferred that increase in average shell size of Rosalina globularis in a core can be used to indicate warmer conditions, while increase in its abundance will indicate moderate conditions. The specimens subjected to lower temperatures, though did not reproduce, were alive. This indicates that under unfavorable conditions, benthic foraminifera may survive but will not reproduce. Thus such conditions may lead to not only decreased abundance but also stunted specimens of benthic foraminifera. The findings can be used to infer past climatic changes from the shallow water regions wherein R. globularis is common (Sliter, 1965; Panieri et al., 2005; Pascual et al., 2008). However, the effect of combination of several physical and chemical factors on $R$. globularis has to be studied before applying its morphological and abundance changes for paleoclimatic interpretation. 


\section{Conclusions}

On the basis of culture experiment carried out on benthic foraminifer Rosalina globularis, wherein it was subjected to a range of temperatures, it is concluded that out of different temperatures $\left(20^{\circ} \mathrm{C}\right.$, $25^{\circ} \mathrm{C}, 27^{\circ} \mathrm{C}, 30^{\circ} \mathrm{C}$ and $35^{\circ} \mathrm{C}$ ), the maximum growth occurs at $30^{\circ} \mathrm{C}$ temperature. The majority of the specimens reproduced at $27^{\circ} \mathrm{C}$ temperature. At very low temperature i.e. at $20^{\circ} \mathrm{C}$, no reproduction was observed and at the highest temperature i.e. at $35^{\circ} \mathrm{C}$ only one specimen reproduced. Thus it is concluded that though Rosalina globularis can tolerate temperatures from $20^{\circ} \mathrm{C}$ to $35^{\circ} \mathrm{C}$, optimum range of temperature for growth and reproduction is relatively narrow. Under the given set of temperature and salinity conditions, the specimens reproduced only asexually indicating that at the given salinity (35\%), temperature does not affect the mode of reproduction in $R$. globularis. The study shows pronounced influence of temperature on the growth, survival and reproduction in benthic foraminifer Rosalina globularis.

\section{Acknowledgements}

The authors are thankful to the Director, National Institute of Oceanography, Goa for his support and permission to submit this work for publication. The help by Dr. Sujata R. Kurtarkar at various stages of the experiment is thankfully acknowledged. We are thankful to the three anonymous reviewers whose comments and suggestions helped improve the manuscript. We are also thankful to the Department of Science and Technology, New Delhi for financial support (SR/S4/ES-74/2003) to RN. 


\section{References}

Bé, A.W.H., Tolderlund, D.S. 1971. Distribution and ecology of living planktonic foraminifera in surface waters of the Atlantic and Indian Ocean. In The Micropaleontology of Oceans (ed. B. M. Funnel and W. R. Riedel), pp. 105-149.

Bandy, O.L. 1963. Larger living foraminifera of the continental borderland of southern California. Cush. Found. Foramin. Res. 14, 121-126.

Boltovskoy, E., Wright, R. 1976. Recent Foraminifera. Dr. W. Junk Publishers, The Hague, 515 p.

Boltovskoy, E., Scott, D.B., Medioli, F.S. 1991. Morphological variations of benthic foraminiferal tests in response to changes in ecological parameters: A review. J. Paleontol. 65, 175-185.

Bradshaw, J.S. 1955. Preliminary laboratory experiments on ecology of foraminiferal populations. Micropaleontology 1, 351-358.

Bradshaw J.S. 1957. Laboratory studies of the rate of growth of the foraminifera. J. Paleontol. 31, 1138-1147.

Bradshaw, J.S. 1961. Laboratory experiments on the ecology of foraminifera. Contr. Cushman Found. Foramin. Res. 12, 87-106.

Carpenter, W.B. 1856. Researches in the foraminifera. Royal Society of London, Phil. Trans. 146, 547-569.

Collins, L.S. 1989. Relationship of environmental gradients to morphologic variation within Bulimina aculeata and Bulimina marginafa, Gulf of Maine area. J. Foramin. Res. 19, 222234.

Gooday, A.J. 2003. Benthic foraminifera (Protista) as tools in deep-water palaeoceanography: environmental influences on faunal characteristics. Adv. Mar. Biol. 46, 1-90.

Guillard, R.R.L., Ryther, J.H. 1962. Studies of marine planktonic diatoms. I. Cyclotella nana Hustedt and Detonula confervacea Cleve. Can. J. Microbiol. 8, 229-239.

Hald, M., Kolstad, V., Polyak, L., Forman, S.L., Herlihy, F.A., Ivanov, G., Nescheretov, A. 1999. Late-glacial and Holocene paleoceanography and sedimentary environments in the St. Anna Trough, Eurasian Arctic Ocean margin. Palaeogeogra., Palaeoclimatol., Palaeoecol. 146, 229-249.

Halfar, J., Ingle, J.C. 2003. Modern warm-temperate and subtropical shallow water benthic foraminifera of the southern Gulf of California, Mexico. J. Foramin. Res. 33, 309-329.

Hemleben, C., Spindler M., Anderson, O.R. 1989. Modern Planktonic Foraminifera, SpringerVerlag, New York, 363 pp.

Hengstum, P.J.V., Reinhardt, E.G., Beddows, P.A., Gabriel, J.J. 2010. Linkages between Holocene paleoclimate and paleohydrogeology preserved in a Yucatan underwater cave. Quat. Sci. Rev. 29, 2788-2798. 
Leorri, E., Martin, R., McLaughlin, P. 2006. Holocene environmental and parasequence development of the St. Jones Estuary, Delaware (USA): Foraminiferal proxies of natural climatic and anthropogenic change. Palaeogeogra., Palaeoclimatol., Palaeoecol. 241, 590-607.

Lewis, K.B., Jenkins, C. 1969. Geographical variations of Nonionella flemingi. Micropaleontology 15, 1-12.

Linshy, V.N., Rana, S.S., Kurtarkar, S.R., Saraswat, R., Nigam, R. 2007. Appraisal of laboratory culture experiments on benthic foraminifera to assess/develop paleoceanographic proxies. Indian J. Mar. Sci. 36, 301-321.

Majewski, W., Anderson, J.B. 2009. Holocene foraminiferal assemblages from Firth of Tay, Antarctic Peninsula: Paleoclimate implications. Mar. Micropaleontol. 73, 135-147.

Murray, J. 2006. Ecology and applications of benthic foraminifera. Cambridge, New York, Melbourne: Cambridge University Press, 426 pp.

Myers, E.H. 1940. Observations on the origin and fate of flagellated gametes in multiple tests of Discorbis (Foraminifera). J. Mar. Biol. Assoc. U.K. 24, 201-226.

Myers, E.H. 1943. Biology, ecology and morphogenesis of a pelagic foraminifer. Stanford Univ. Press. Biol. Ser. 9, 5-30.

Nigam, R., Khare, N. (1995). Significance of correspondence between river discharge and proloculus size of benthic foraminifera in paleomonsoonal studies. Geo-Mar. Lett. 15, 45-50.

Nigam, R., Khare, N., Nair, R.R. 1995. Foraminiferal evidences for 77-year cycles of droughts in India and its possible modulation by the gleissberg solar cycle. J. Coast. Res. 11, 10991107.

Nigam, R., Khare, N. 1999. Spatial and temporal distribution of foraminifera in sediments off the central west coast of India and use of their test morphologies for the reconstruction of paleomonsoonal precipitation. Micropaleontology 45, 285-303.

Nigam, R., Saraswat, R., Kurtarkar, S.R. 2006. Laboratory experiment to study the effect of salinity variations on benthic foraminiferal species - Pararotalia nipponica (Asano). J. Geol. Soc. India $67,41-46$.

Nigam, R., Kurtarkar, S.R., Saraswat, R., Linshy, V.N., Rana, S.S. 2008. Response of benthic foraminifera Rosalina leei to different temperature and salinity, under laboratory culture experiment. J. Mar. Biol. Assoc. UK 88, 699-704.

Nigam, R., Prasad, V., Mazumder, A., Garg, R., Saraswat, R. and Henriques, P.J. 2009. Late Holocene changes in hypoxia off the west coast of India: Micropalaeontological evidences. Curr. Sci. 96, 708-713.

Panieri, G., Gamberi, F., Marani, M., Barbieri R. 2005. Benthic foraminifera from a recent, shallowwater hydrothermal environment in the Aeolian Arc (Tyrrhenian Sea). Mar. Geol. 218, 207229. 
Pascual, A., Lazaro, J. R., Rubio, M. M., Jouanneau, J.M., Weber, O. 2008. A survey of the benthic microfauna (foraminifera, Ostracoda) on the Basque shelf, southern Bay of Biscay. J. Mar. Syst. 72, 35-63.

Phleger, F.B. and Hamilton, W.A. (1946). Foraminifera of two submarine cores from the North Atlantic Basin. Geol. Soc. America Bull. 57, 951-966.

Schnitker, D. 1974. Ecophenotypic variation in Ammonia beccarii (Linné). J. Foramin. Res. 4, 216223.

Sliter, W.V. 1965. Laboratory experiments on the life cycle and ecologic controls of Rosalina globularis d'Orbigny. J. Protozool. 12, 210-215.

Theyer, F. 1971. Size-depth variation in Cyclammina cancellata Brady, Peru-Chile Trench area. Antarctic Research Ser. 15, 309-318.

Walton, W.R., Sloan, B.J. 1990. The genus Ammonia Brünnich, 1772: its geographic distribution and morphologic variability. J. Foramin. Res. 20, 128-156.

\section{Legend to Figures:}

Figure 1: $\quad$ Schematic diagram of the experimental set-up

Figure 2: $\quad$ Average growth in Rosalina globularis at different temperatures. The error bars show standard deviation of growth between successive measurements in replicate sets.

Figure 3: $\quad$ Percentage of specimens reproduced. The error bars show standard deviation of percentage of specimens reproduced in replicate sets.

Plate 1: $\quad$ Growth and reproduction in Rosalina globularis $($ Scale Bar $=100 \mu \mathrm{m})$ 

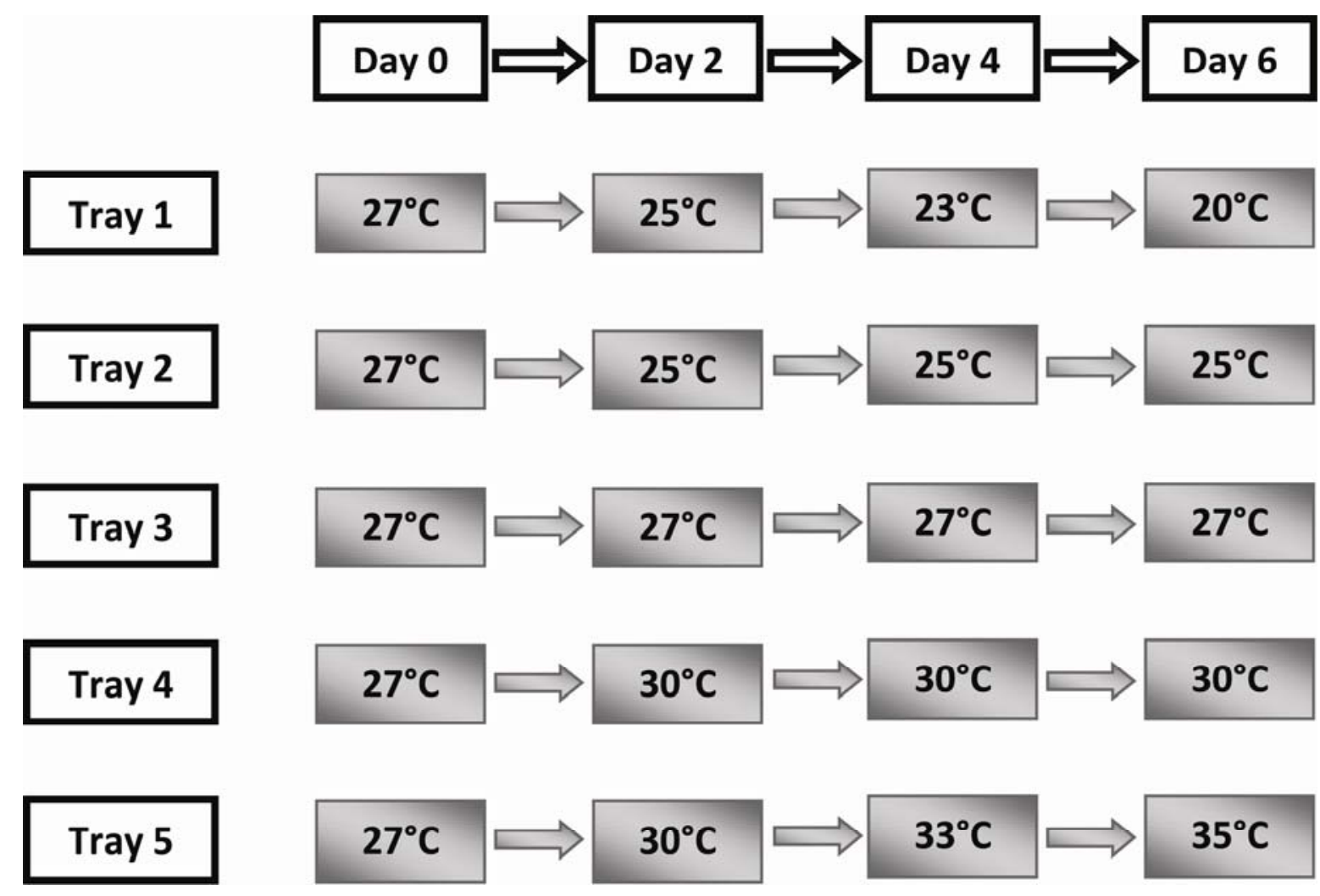

Figure 1 


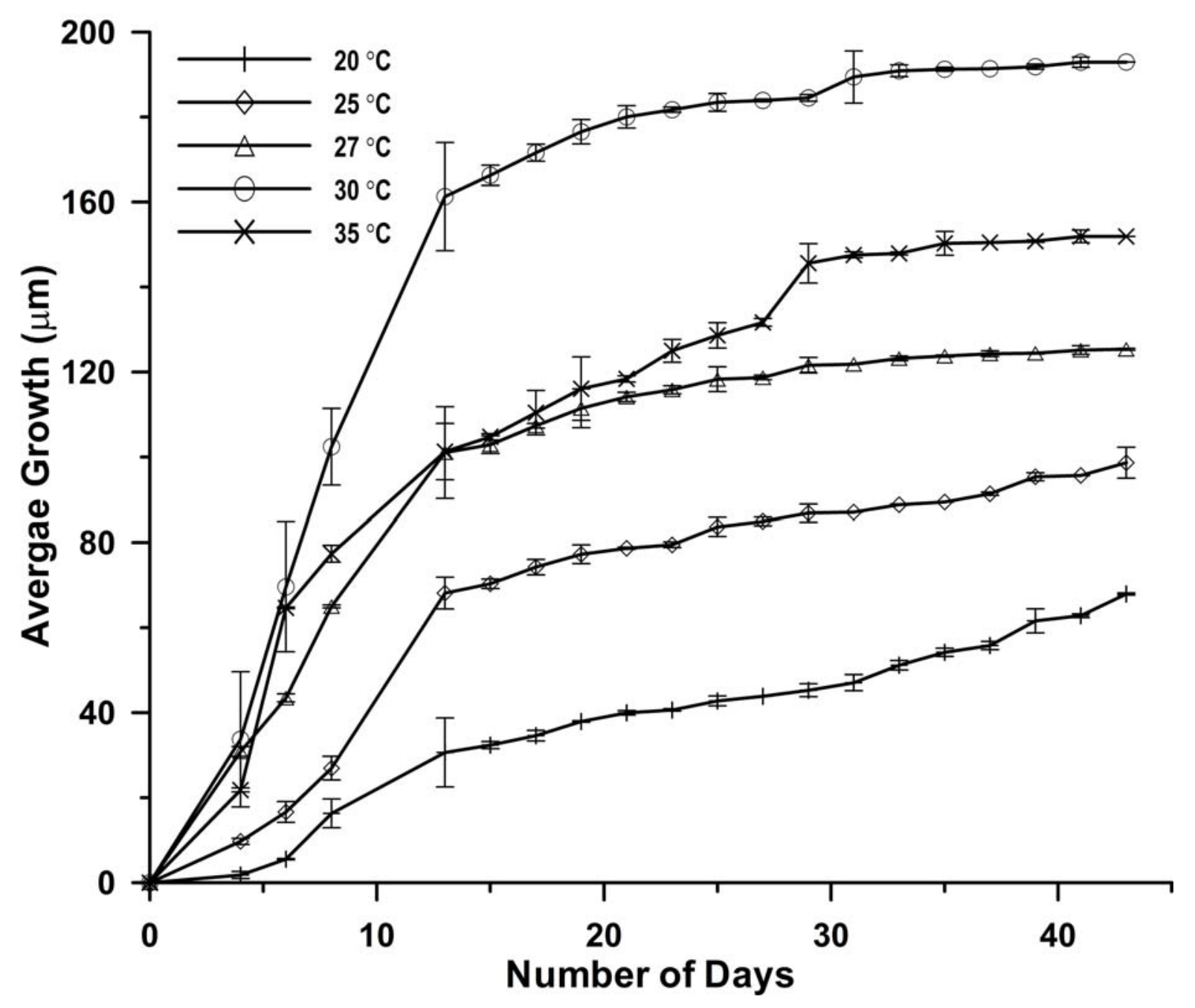

Figure 2 


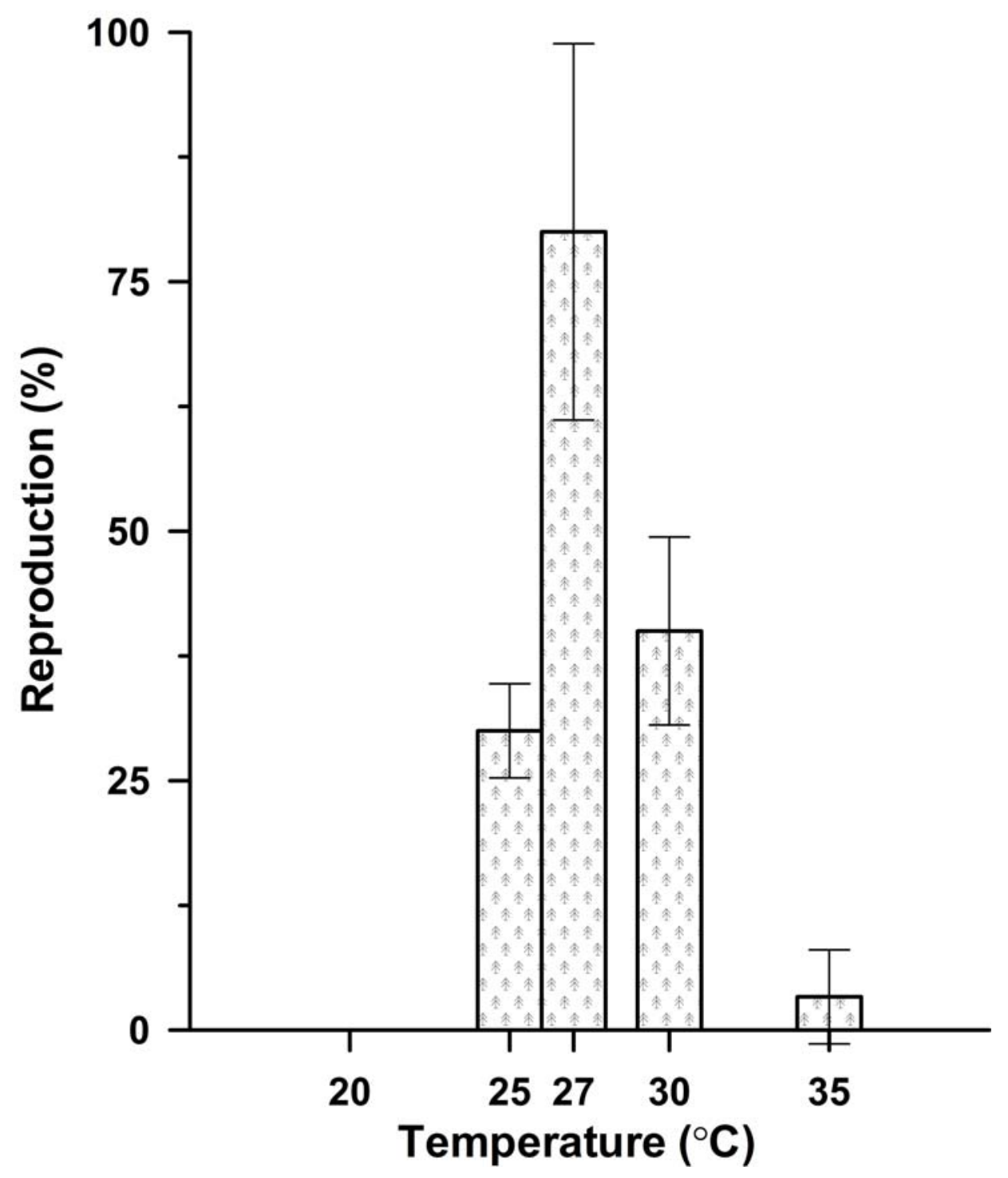

Figure 3 


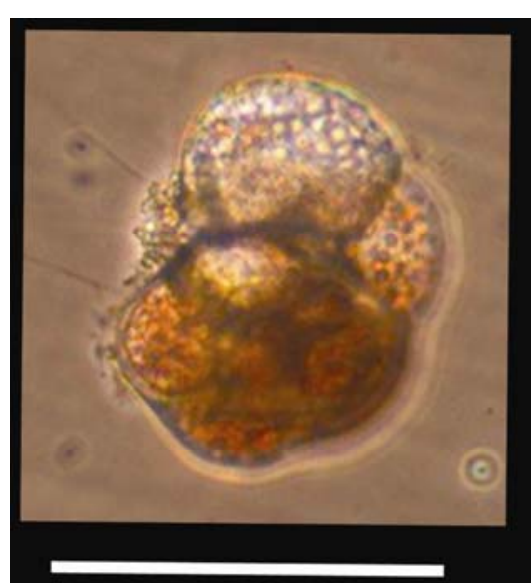

A

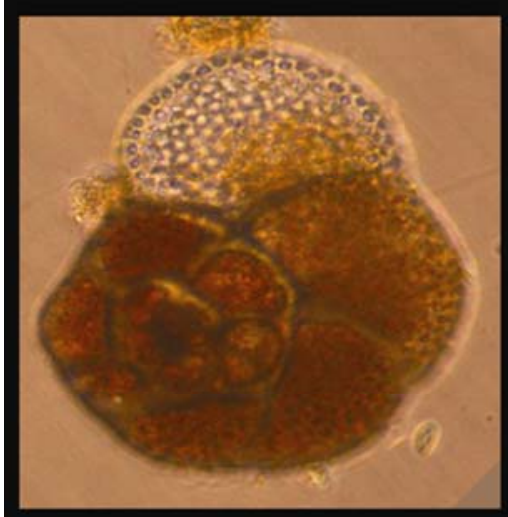

D

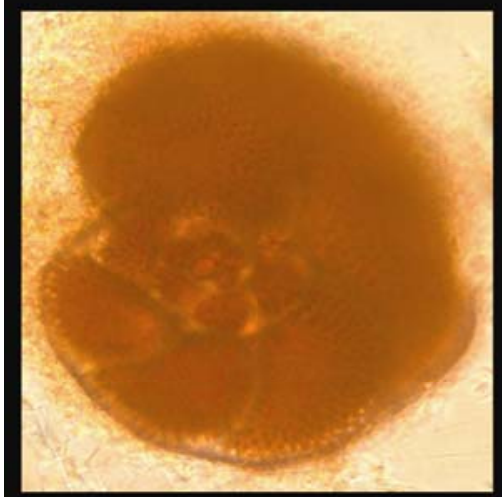

G
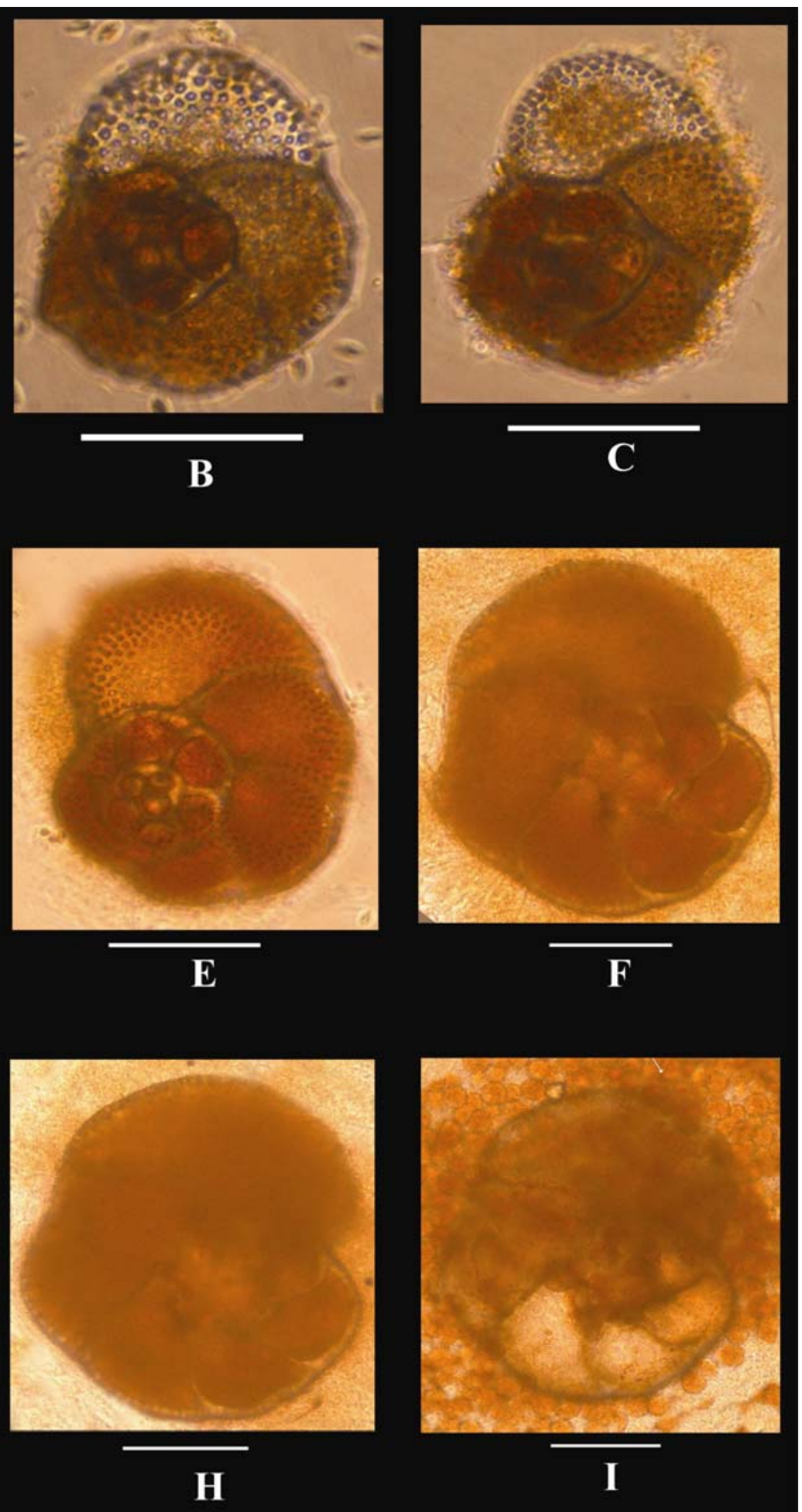

Plate 1 